\title{
ARYLHYDROCARBON RECEPTOR (AHR) EXPRESSION IN BOVINE OVARY AND UTERUS DURING ESTROUS CYCLE AND EARLY PREGNANCY :AN IMMUNOHISTOCHEMICAL STUDY
}

\author{
Atif Hasan \\ Department of Anatomy and Embryology, Faculty of Veterinary Medicine, \\ Kafrelsheikh University
}

\begin{abstract}
The arylhydrocarbon receptor $(A h R)$ is a ligand activated transcription factor. The AhR was found in embryos, fetuses and in genital tract tissues of some lab animals and human; However, Its role in reproduction and fertility in different species is still to be elucidated.

By employing immunohistochemistry in the current study, AhR expression was studied in bovine ovary and uterus in cyclic and early pregnant cows .

In the ovary; during estrous, AhR was expressed in the stromal (interstitial) cells while in diestrous and early pregnancy it was found in luteal and stromal cells. In the uterus, during diestrous, the receptor was always expressed in connective cells and in the endometrial epithelium showing localized cytoplasmic staining apical to the nucleus; nuclear staining was only observed in the uterine glands. During estrous, the receptor was only localized in the connective tissue cells while the epithelium was immunonegative. In the uterus at day 13 of early pregnancy, similar staining pattern as with diestrous was recorded. Myometrium was always immunonegative.
\end{abstract}


Taken together, AhR was expressed during diestrous and early pregnancy in the endometrial epithelium and corpus luteum and during estrous was mainly in stromal cells in both uterus and ovary. The obtained results points to a relationship between the AhR up regulation and the hormone-induced cellular changes in cyclic and early pregnant cows.

\section{INTRODUCTION}

The Arylhydrocarbon receptor $(\mathrm{AhR})$ is a ligand activated transcription factor resides in the cytoplasm and regulate a broad spectrum of genes involved in numerous cellular functions (Bock 1993 ; Schmidt and Bradfield, 1996; Hahn, 1998). It was first identified in 1976 by using radioligand $\left[{ }^{3} \mathrm{H}\right]$ TCDD (2,3,7.8-tetrachlorodibenzo-pdioxin) which bound specifically and with high affinity to a cytosolic hepatic protein from C57BL/6 mice (Poland et al., 1976). The unligand AhR has a half life of about eight hours (Denison et al., 1986; Gudas et al., 1986; Pollenz et al., 1994; Swanson and Perdew, 1993). Upon ligand binding, the AhR is activated and translocate to the nucleus where it heterodimerize with the arylhydrocarbon nuclear translocator then bind a DNA response element termed xenobiotic responsive element (XRE) to induces a variety of genes, the so called AhR gene battery (Nebert et al., 1993; Schmidt and Bradfield, 1996).

Although numerous xenobiotics and naturally occurring biological compounds are known to react with the AhR it remains an orphan receptor because a strictly physiological ligand is still unknown (Adachi et al., 2001).

The AhR is expressed in various mammalian tissues with highest levels of protein constantly found in the lung (Carver et al., 1994). It is also expressed in liver, thymus, kidney, spleen, placenta ( $\boldsymbol{L} \boldsymbol{i}$ et al., Kafrelsheikh Vet. Med. J. Vol. 5 No. 2 (2007) 
1994), human uterus (Kuechenhoff et al., 1999b), rabbit uterus (Tscheudschilsuren et al., 1999; Hasan and Fischer, 2001), rabbit ovary (Hasan and Fischer, 2003), mouse urinary tract (Bryant et al., 1997) and male rat reproductive tract (Roman et al., 1998). In the bovine ovary it was expressed in the oocyte of the primordial follicle (Pocar et al., 2000).

Regarding reproductive organs, AhR expression in human endometrial epithelium seems cyclically dependent and was maximally expressed at the time of ovulation (Kuechenhoff et al., 1999b). In the human placenta, AhR has been shown to be abundantly present (Manchester et al., 1987; Dolwick et al., 1993) while in the rabbit placenta, it is specifically expressed in decidua cells (Tscheudschilsuren et al.,1999b).

The physiological function(s) of AhR still need further studies. Information about AhR expression in farm animals are scarce. The current study was carried out on uterine and ovarian tissues from cyclic and early pregnant cows to elucidate the potential role of the AhR in cows reproduction.

\section{MATERIALS AND METHODS}

\section{Sampling:}

Uterine and ovarian specimens were collected from Friesian cows at slaughterhouse. Estrous phase was determined by presence of mature graafian follicle and diestrous phase by presence of corpus luteum on the ovary. 
Uterine samples were collected from early pregnant cows at day 13 considering the day of insemination is the day 0 and pregnancy was confirmed by presence of blastocysts in uteri. Samples were immediately fixed in Bouin's solution for 18 hours. Tissues were routinely processed and paraffin embedded, then $5 \mu \mathrm{m}$ thick sections were obtained by rotary microtome.

\section{Immunohistochemistry:}

After treatment with xylol and rehydration by descending dilutions of ethyl alcohol, Sections were subjected to immunohistochemistry (using an indirect method) by using peroxidase enzyme activity. The endogenous peroxidases were blocked by incubation of the sections in $3 \%(\mathrm{v} / \mathrm{v}) \mathrm{H}_{2} \mathrm{O}_{2}$ in methanol at room temperature for $30 \mathrm{~min}$. Sections were washed three times for five minutes $(3 \times 5)$ by PBS-T. All reagents were dissolved in 3\% bovine serum albumen (BSA) in PBS-T.

Unspecific reactions were blocked by normal goat serum, $10 \%$ $(\mathrm{v} / \mathrm{v})$ for 30 minutes at room temperature. Then the primary antibody (monoclonal mouse anti-AhR; MA1-514, Dianova, Germany) was applied at dilution of 1:500 and incubated at $4^{\circ} \mathrm{C}$ overnight. Sections were carefully washed $3 \times 5$ with PBST. Then sections were incubated with the secondary antibody, a peroxidase conjugated polyclonal goat anti-mouse antibody (115-036-003; Dianova - Germany) at a dilution of 1:250 for 1 hour at room temperature. After three times of washing (3x5) in PBS-T, immunoreaction was visualized by $10 \%$ (v/v) 3,3diaminobezidine (chromogen substrate - 34062; Pierce, Rockford, IL,

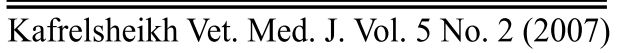


USA) in stable hydrogen peroxide for 2 min. Afterwards the background was stained light blue with haematoxylin for $10 \mathrm{sec}$. Finally, the sections were covered in entellan (Merck, Darmstadt, Germany) and examined under light microscope. Negative controls omitting the primary antibody were included in each experiment and were always blank.

\section{RESULTS}

Aryl hydrocarbon receptor (AhR) showed stage and tissue specific expression in the bovine uterus and ovary.

\section{In the uterus:}

A-At estrous phase; AhR was strongly expressed in the subepithelial stromal cells in the endometrium (Fig.1A,B) and in the perimetrium (Fig.1E,F); Walls of blood vessels were immunopositive (Fig.1D). On the other hand, Luminal epithelium (Fig.1B), uterine glands (Fig.1A,C) and Myometrium (Fig.1E) were immunonegative.

B- At diestrus phase; Strong expression of the AhR was recorded in both luminal epithelium and uterine glands. In the luminal epithelium, the reaction was localized cytoplasmic apical to the nucleus in the stained cells (Fig.2A,G). In the uterine glands, two forms of immunopositive reaction were observed; the first form was localized cytoplasmic apical to the nucleus in all uterine glands with negative nuclei (Fig.2 A,B,C); the second form was nuclear with diffuse cytoplasmic staining only in the tunica functionalis (superficial glands) of the endometrium (Fig.2 E,F). 
Stromal cells were immunopositive in both endometrium and perimetrium (Fig.2 C,G) and (Fig.2 D,H,I) respectively.

Myometrium was immunonegative (Fig.2 D,H).

C- In the uterus at day 13 of pregnancy; In the luminal epithelium, AhR was strongly expressed in the form of localized cytoplasmic apical to the nucleus (Fig.3 C,D); the reaction was specially extensive at the uterine caruncle (Fig.3 B). In the uterine glands, although many of them were immunonegative (Fig.3 A,F), others were immunopositive showing nuclear and light cytoplasmic staining (Fig.3 G).

Stromal cells were immunopositive showing cytoplasmic and nuclear staining (Fig.3 C,E).

Myometrium was immunonegative (Data not shown).

\section{In the ovary:}

During estrous, AhR was strongly expressed in the stromal cells (Fig.4 A,B,C) these cells were more numerous during estrous in the vicinity ovarian follicle and blood vessels (Fig.4C). During diestrous, Lutein cells were expressing AhR showing diffuse cytoplasmic staining (Fig.4 D). 


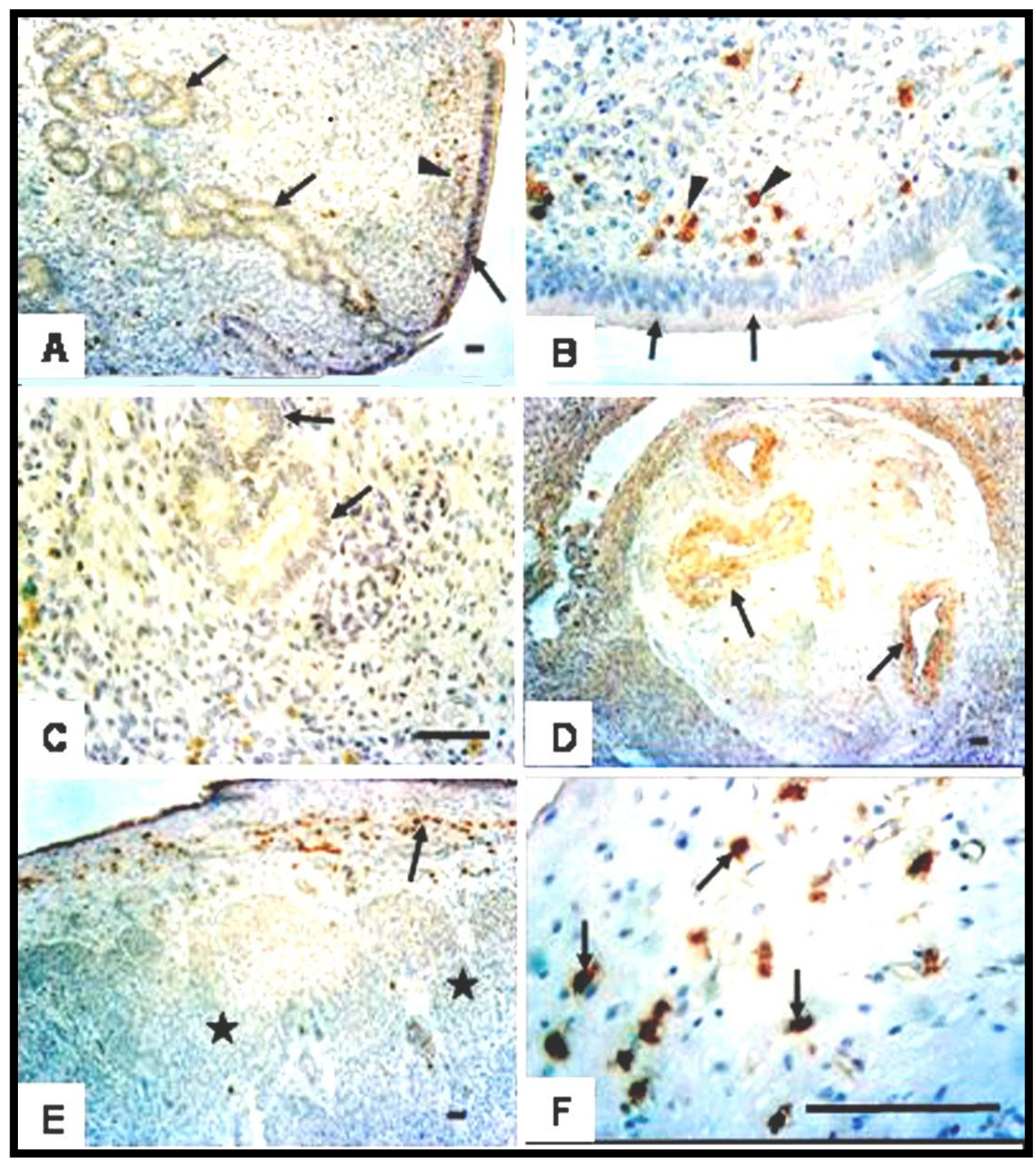

Fig (1): In the uterus during oestrus; both luminal and glandular epithelium was negative (A,B,C arrows). AhR was strongly expressed in stromal cells (A,B-arrowheads). Myometrium was immunonegative (E, stars). In the perimetrium many stromal cells were immunopositive. (E,F, arrows). Smooth muscle of the blood vessels were immunopositive (D, arrows). Bars (25um). 

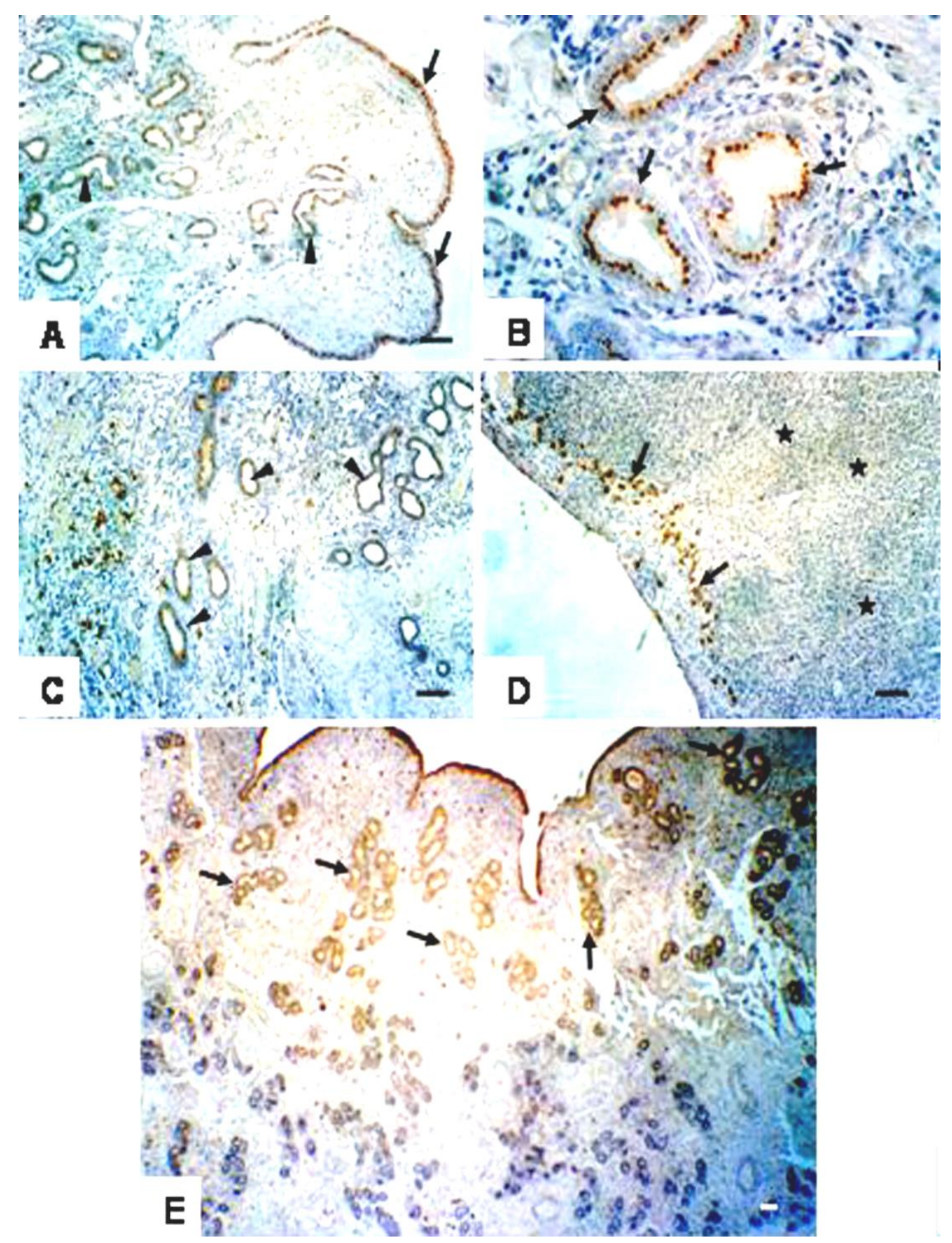

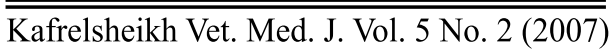




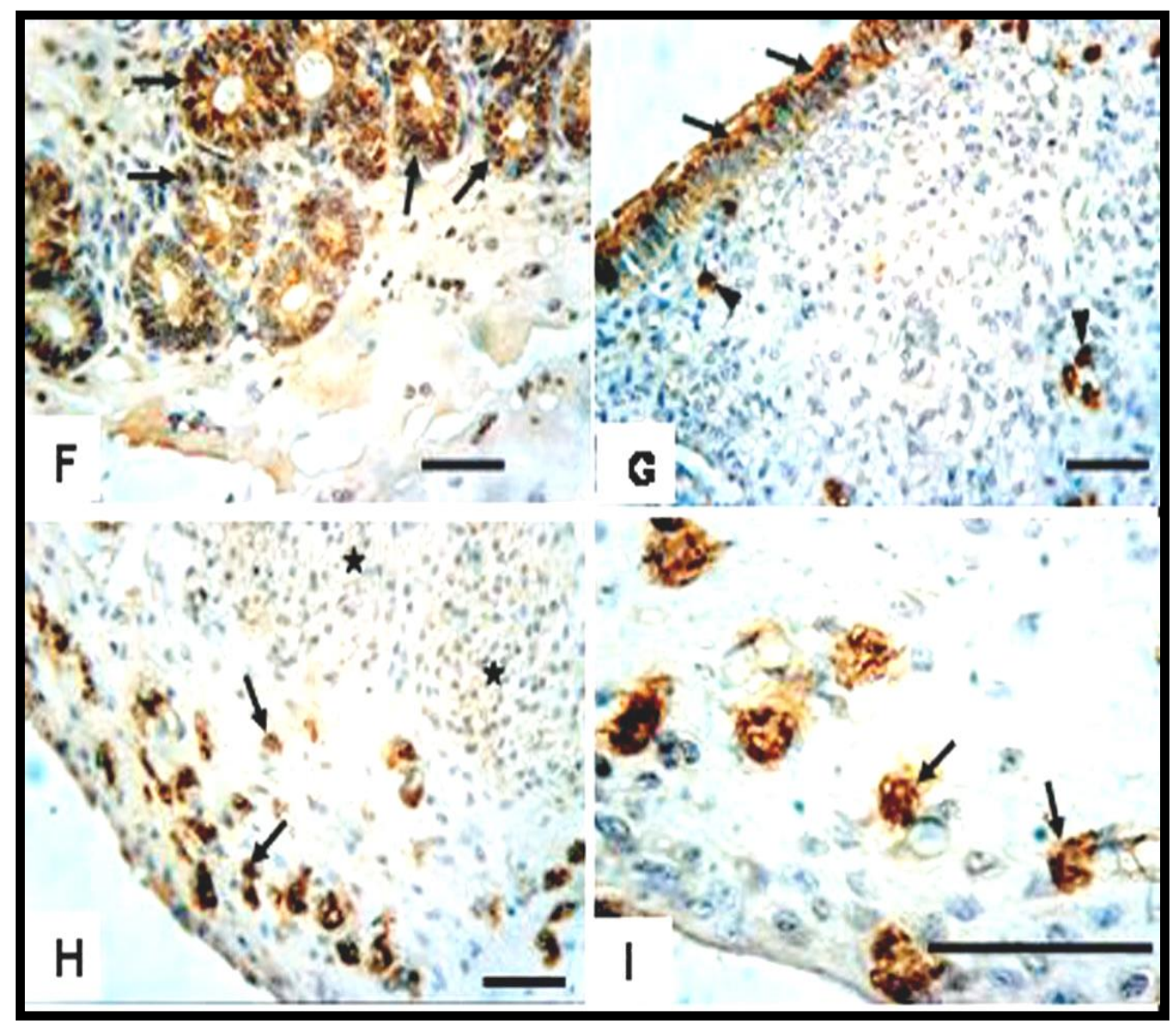

Fig. (2): In the uterus at diestrus; the luminal epithelium was immunopositive for AhR showing localized cytoplasmic reaction (A,G, arrows). Uterine glands showed localized cytoplasmic reaction in some cows (B, arrows) and nuclear and cytoplasmic in others ( $\mathrm{F}$, arrows). In the uterine glands, nuclear staining was only in tunica functionalis $(\mathrm{F}$, arrows) but the localized cytoplasmic staining was in all uterine glands ( A,C, arrowheads). Stromal cells in the endometrium (G arrowheads) and perimetrium (D,H,I, arrows) were expressing AhR showing cytoplasmic andlor nuclear staining. Myometrium was immunonegative (D,H stars). Bars (25um). 


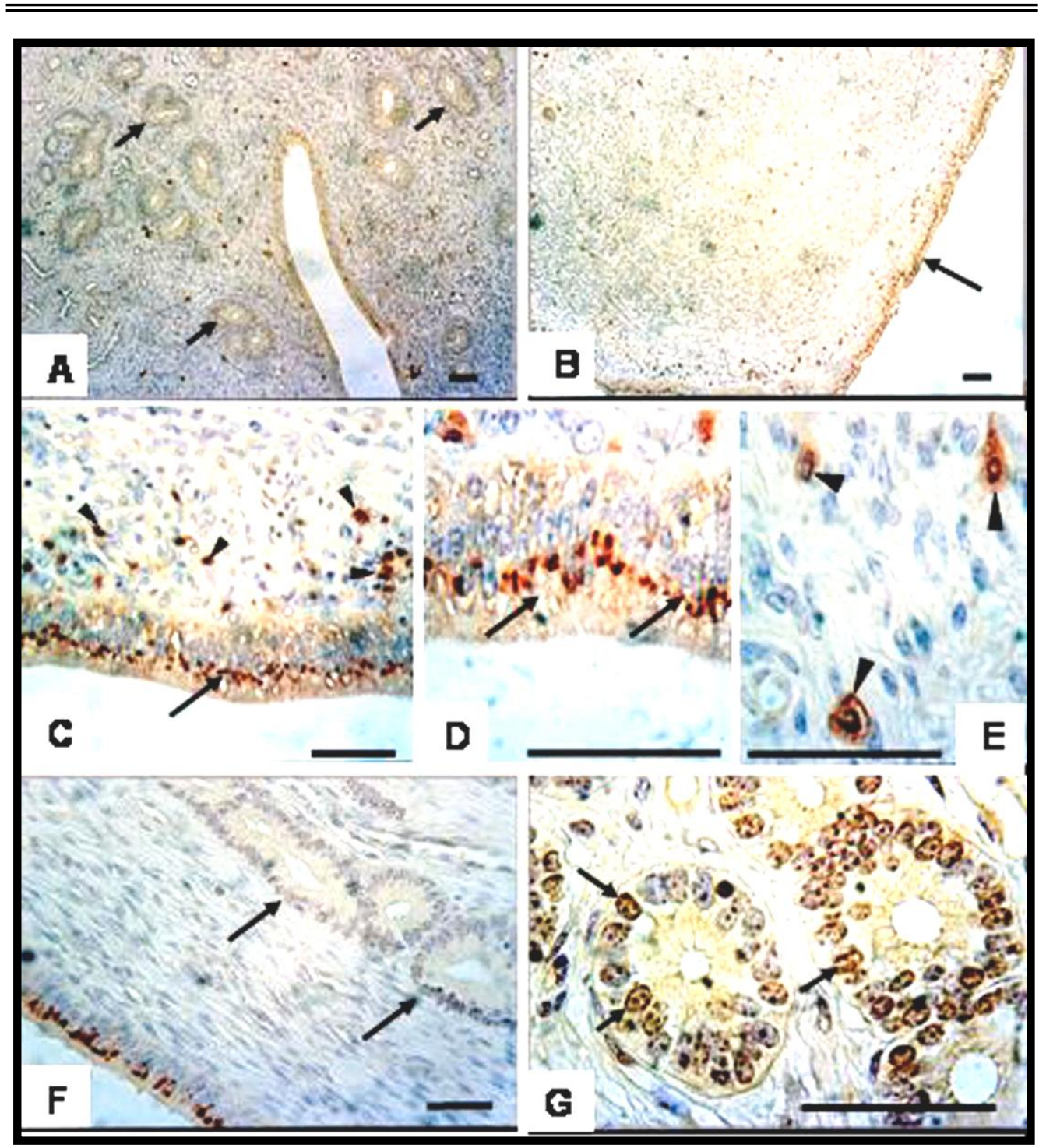

Fig. (3): In the uterus at day 13 of pregnancy, AhR was expressed in luminal epithelium as localized cytoplasmic staining (B,C,D arrows). In the uterine glands; although many of them was immunonegative (A,F, arrows) others were immunopositive showing nuclear staining $(\mathrm{G}$, arrows). Stromal cells were imunopositive (C,F arrowheads).Bars (25um). 


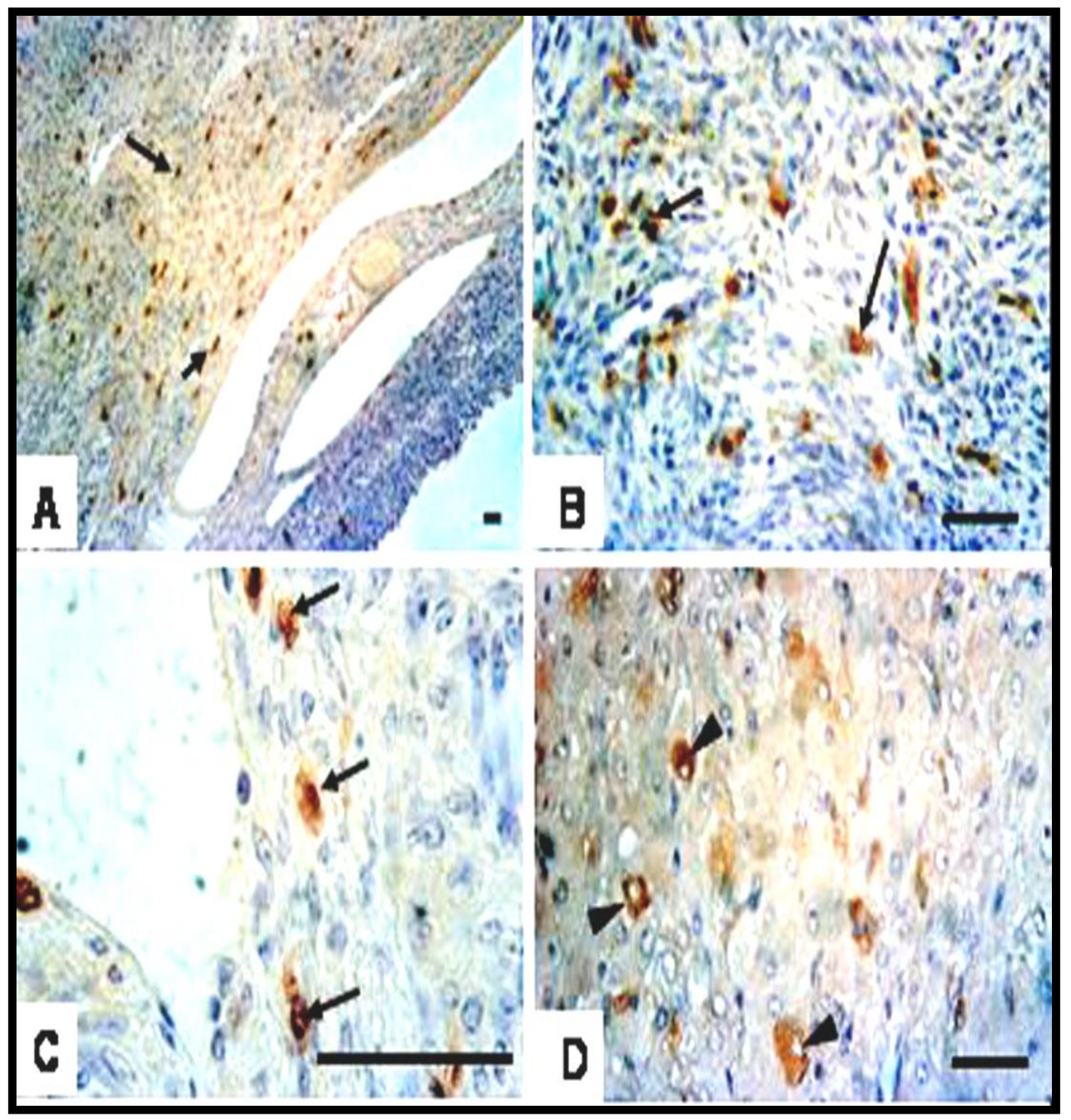

Fig. (4): In the ovary during oestrus; AhR was strongly expressed in stromal cells showing cytoplasmic and nuclear staining (A,B,C arrows). During diestrus; lutein cells in the corpus luteum were expressing $A h R$ in the form of cytoplasmic staining (D, arrowheads). Bars (25um). 


\section{DISCUSSION}

The expression pattern of the AhR in bovine uterus and ovary showed stage and tissue specific pattern. In the uterus, the receptor was predominantly expressed in stromal cells in both endometrium and perimetrium during estrous, diestrous and early pregnancy; in a comparable findings, $\mathrm{AhR}$ was found to be expressed in endometrial stroma pre and post implantation in pregnant and pseudopregnant rabbits and a role of the receptor in implantation and placentation was hypothesized (Tscheudschilsuren et al, 1999b; Hasan and Fischer, 2001). In cow's uterus; it is known that immune and mast cells are present in the endometrium being specially numerous during estrous (Dellmann and Eurell, 1998).

In the cow's uterus during estrous, neither luminal epithelium nor uterine glands were expressing AhR inspite of the high estrogen hormone level; different results were obtained in the human endometrium where the receptor was high regulated around the time of ovulation (Kuechenhoff et al, 1999b); in addition, in the rabbit uterus, the receptor was also high regulated during the preimplantation period (Hasan and Fischer, 2001); it may be due to the relatively long preimplantation period (up to day $16-18$ post ovulation) in bovine (Dellmann and Eurell, 1998) render the high regulation of the receptor slower than that in the human and rabbit.

Later on during diestrous, high regulation of the receptor was found in both luminal epithelium and uterine glands; in addition, nuclear staining was observed in the uterine gland; these findings indicate an 
involvement of the receptor in the endometrial function and means activation of the AhR by its translocation to the nucleus; it is known that, after ligand binding the AhR is translocated into the nucleus (Hoffman et al, 1991; Reyes et al, 1992; Whitelaw et al, 1993) and nuclear localisation is a clear indication for the recruitement of the AhR to active transcription sites (Elbi et al., 2002); in addition, AhR was found to be activated in the absence of added exogenous ligands suggesting the presence of an endogenous AhR ligand(s) (Sadek and Allen-Hoffman, 1994; Ma and Whitlock, 1996) however, endogenous ligand for AhR is still unknown.

AhR expression at day 13 of early pregnancy was similar to that found during diestrous in cyclic cows indicating a primary maternal control, similar results were found in the pregnant and pseudopregnant rabbit (Hasan and Fischer, 2001).

It is worthy to state that, AhR was strongly expressed in the luminal epithelium that cover the uterine caruncle (site of implantation in cows) more than the intercaruncular areas indicating a potential role of the receptor in the feto-maternal interaction; in comparable findings, AhR was expressed in endometrial stromal and decidual cells of the rabbit uterus (Tscheudschilsuren et al, 1999b; Hasan and Fischer, 2001).

Results of the current study revealed that the AhR expression in the bovine uterus is influenced by the circulating ovarian steroids (estrogen and progesterone). In a laboratory experiment where juvenile rabbits 
were treated with estrogen and progesterone hormones; it was found that AhR expression was up regulated in the uterus together with proliferative changes similar to that happen during the preimplantation period in mature rabbits (Hasan and Fischer, 2001). Although AhR is not a member of the steroid hormone receptor superfamily, its cross- talk with steroid hormone receptors is not uncommon (Burbach et al, 1992; Ema et al, 1992; Wormke et al, 2000).

In the cow's ovary; AhR was expressed in stromal cells during estrous and diestrous, and lutein cells during diestrous. Pocar et al., 2000, found that AhR was expressed in the oocyte of the primordial follicle of the bovine ovary, also Hasan and Fischer, 2003 found that the interstitial glands of the rabbit ovary were also expressing AhR. Results of the current study with others indicates a potential role of the AhR in the ovarian activity.

Further investigations are required to identify the immunopositive stromal cells in the uterus and ovary and to clarify the role of the AhR in these cells. The unique expression of AhR in the uterus of the cow and rabbit render the uterus a typical organ for further studies on the AhR physiology.

In conculsion; the AhR was expressed in bovine uterus and ovary in a stage and tissue dependent manner specially in the physiologically active cells as epithelial and stromal cells. AhR is involved in the process of progestational proliferation in the uterus of cyclic and early pregnant cows. 


\section{REFERENCES}

- Adachi J., Mori Y., Matsui S., Takigami H., Fujino J., Kitagawa H., Miller III C.A., Kato T., Saeki K., Matsuda T. (2001): Indirubin and indigo are potent aryl hydrocarbon receptor ligands present in human urine. J Biol Chem 276: $31475-31478$.

- Bock K.W. (1993): Arylhydrocarbon or dioxin receptor: Biologic and Toxic responses. Rev Physiol Biochem Pharmacol 125: 1- 40.

- Bryant P., Clark G.C., Probst M.R., Abbott B.A. (1997): Effects of TCDD on Ah receptor, ARNT, EGF, and TGF- $\alpha$ expression in embryonic mouse urinary tract, Teratology 55: $326-337$.

- Burbach K.M., Poland A., Bradfield C.A. (1992): Cloning of the $\mathrm{Ah}$ receptor cDNA reveals a distinctive ligand-activated transcription factor, Proc. Natl. Acad. Sci. USA 89: 8185 8189.

- Carver L.A., Hogenesch J.B., Brandfield C.A. (1994): Tissue specific expression of the rat Ah-receptor and ARNT mRNAs, Nucleic Acids Res. 22: 3038 - 3044.

- Dellmann HD., Eurell J. (1998): Textbook of Veterinary Histology. Fifth edition. Williams \& Wilkins. A waverly company. Baltimore, Philadelphia, London, Paris, Bangkok, Buenos Aires, Hong Kong, Munich, Sydney, Tokyo, Wroclaw. 
- Denison M.S., Vella L.M., Okey A.B. (1986): Structure and function of the Ah receptor for 2, 3, 7, 8- tetrachlorodibenzo-pdioxin: species difference in molecular properties of the receptors from mouse and rat hepatic cytosols, J. Biol. Chem. 61: $3987-3995$.

- Dolwick K.M., Schmidt J.V., Carver L.A., Swanson H.I., Bradfield C.A. (1993): Cloning and expression of a human Ah receptor cDNA. Mol Pharmacol 44: 911-917.

- Elbi C, Misteli T, Hager GL (2002): Recruitment of dioxin receptor to active transcription sites. Mol Biol Cell 13: 20012015.

- Ema M., Sogawa K., Watanabe Y., Chujoh Y., Matsushita N., Gotoh O., Funae Y., Fujii-Kuriyama Y. (1992): cDNA cloning and structure of mouse putative Ah receptor, Biochem. Biophys. Res. Commun. 184: 246 - 253.

- Gudas J.M., Karenlampi S.O., Hankinson O. (1986): Intracellular location of the Ah receptor, J. cell Physiol. 128: 441.

- Hahn M.E. (1998): The aryl hydrocarbon receptor: a comparative perspective, Comparative Biochem. Physiol. Part C 121: $23-53$.

- Hasan A., Fischer B. (2001): Hormonal control of arylhydrocarbon receptor (AhR) expression in the 
preimplantation rabbit uterus, Anat. Embryol. 204: 189 - 196.

- Hasan A., Fischer B. (2003): Epithelial cells in the oviduct and vagina ans steroid synthesizing cells in the rabbit ovary express AhR and ARNT, Anat. Embryol. 207:9 - 18.

- Hoffman EC, Reyes H, Chu F-F, Sander F, Conley LH, Brooks BA, Hankinson $O$ (1991): Cloning of a factor required for activity of the Ah (dioxin) receptor, Science 252: $954-958$.

- Kuechenhoff A., Seliger G., Klonisch T., Tschenschilsuren G., Kaltwasser P., Seliger E., Buchmann J., Fischer B. (1999b): Arylhydrocarbon receptor expression in the human endometrium, Fertil. Steril. 71: $354-360$.

- Li, W., Donat S., Dohr O., Unfried K., Abel J. (1994): Ah receptor in different tissues of C57BL/6J and DBA/2J mice: Use of competitive polymerase chain reaction to measure Ahreceptor mRNA expression. Arch. Biochem. Biophys. 315, 279 -284 .

- Ma Q, Whitlock JP JR (1996): The aromatic hydrocarbon receptor modulates the Hepa1C1C7 cell cycle and differentiated state independently of dioxin, Mol. Cell Biol. 16: $2144-2150$.

- Manchester D.K., Gordan S.K., Golas C.L.,Roberts E.A., Okey A.B. (1987): Ah receptor in human placenta: stabilization by molybdate and characterization of binding of 2,3,7,8tetrachlorodibenzo-p-dioxin, 3-methylcholanthrene and 
benzo(a)pyrene. Cancer Res 47: 4861-4868.

- Nebert D.W., Puga A.,Vasiliou V. (1993): Role of the Ah receptor and the dioxin-inducible [Ah] gene battery in toxicity, cancer and signal transduction. Ann NY Acad Sci 685: 624640.

- Pocar P., Augustin R., Hasan A., Fischer B. (2000): Immunolocalisation of arylhydrocarbon receptor (AhR) and ARNT in the female reproductive tract in cattle throughout the oestrus cycle. Joint Winter Meeting der Society for the Study of Fertility/Vereniging voor Fertiliteitsstudie, Utrecht (NL) 15 16 Dezember 2000 Jreprod Fert Abstract Series No 26 Abstract 14: 8-9.

- Poland A., Glover E., Kende A.S. (1976): Stereospesific, high affinity binding of 2,3,7,8-tetrachlorodibenzo-P-dioxin by hepatic cytosol. J Biol Chem 251: 4936 - 4946.

- Pollenz R.S., Sattler C.A., Poland A. (1994): The aryl hydrocarbon receptor and aryl hydrocarbon receptor nuclear translocator protein show distinct subcellular localizations in Hepa 1c1c7 cells by immunofluorescence microscopy, Mol. Pharmacol. 45: 428 - 438.

- Reyes H., Reiz-Porszasz S., Hankinson O. (1992): Identification of the Ah receptor nuclear translocator protein (ARNT) as a component of the DNA binding form of the Ah receptor, Sci. 256: $1193-1195$. 
- Roman B.L., Pollenz R.S., Peterson R.E. (1998): Responsiveness of the adult male rat reproductive tract to 2,3,7,8-tetrachlorodibenzo-p-dioxin exposure: Ah receptor and ARNT expression, CYP1A1 induction, and Ah-receptor down regulation, Toxicol. Appl. Pharmacol. 150: 228 - 239.

- Sadek C.M., Allen-Hoffman B.L. (1994): Suspensionmediated induction of hepa1C1C7 CYP1A1 expression is dependent on the Ah receptor signal transduction pathway, J. Biol. Chem. 269: $31505-31509$.

- Schmidt J.V., Bradfield C.A., (1996): Ah receptor signaling pathways. Annu Rev Biol 12: 55-89.

- Swanson H.I., Perdew G.H. (1993): Half life of arylhydrocarbon receptor in Hepa-1 cells: evidence for liganddependent alterations in cytosolic receptor levels, Arch. Biochem. Biophys. 302: $167-174$.

- Tscheudschilsuren G., Hombach-Klonisch S., Küchenhoff A., Fischer B., Klonisch T. (1999b): Expression of the aryl hydrocarbon receptor and the aryl hydrocarbon nuclear translocator during early gestation in the rabbit uterus, Toxicol. Appl Pharmacol. 160:

$231-237$.

- Whitelaw M., Göttlicher M., Gustafsson J.A., Poellinger L. 
(1993): Definition of a novel ligand binding domain of a nuclear bHLH receptor: Co-localization of ligand and hsp90 binding of the dioxin receptor, EMBOJ 12: 4169 - 4179.

- Wormke M., Castro-Rivera E., Chen I., Safe S. (2000): Estrogen and arylhydrocarbon receptor expression and crosstalk in human ishikawa endometrial cancer cells, J. Steroid Chem. Mol. Biol. 72: 197 - 207.

\section{Acknowledgement:}

I am indebted and thankful to Prof. Bernd Fischer (Institute of Anatomy and Cell biology- Faculty of Medicine - Martin Luther University- Germany) who allowed me to do this work in his lab under his supervision and generously offered necessary materials and antibodies.

I am also grateful to Prof. Dr Khalil Abou Essa (Department of Histology - Faculty of Veterinary Medicine - Kafrelsheikh University) for his valuable scientific and technical help.

$$
\begin{aligned}
& \text { تعبير مستقبل الهيدروكربونات الطيارة في مبيض ورحم الأبقار أثناء دورة الثياع } \\
& \text { وبداية الحمل: در اسة نسجو كيمباء مناعية مبرونية } \\
& \text { د./ - داطف حسن } \\
& \text { قسم التشريح و الأجنة - كلية الطب البيطري - جامعة كفر الثيخ }
\end{aligned}
$$


مستقبل الهيدروكربونات الطيارة ينشط بعد اتصاله بمنشطه الخاص. وهذا المستقبل ثبت وجوده في أجنة و أنسجة الأعضاء التناسلية في حيوانات المعامل و الإنسان و مع ذلك فان دوره في التكاثر مازال تحت الدراسة.

في هذه الدراسة وباستخدام النسجوكيمياء المناعية تم دراسة مستقبل الهيدروكربونات الطيارة في

مبيض ورحم الأبقار أثناء دورة الثباع وبداية الحمل. في المبيض و أثناء دورة الثباع، هذا المستقبل كان موجودا في الخلايا الضامة و أثثاء فترة ما بعد الثباع كان المستقبل موجودا في خلايا الجسم الأصفر ـ أما في الرحم و أثناء فتزة ما بعد الثياع فقد كان المستقبل موجودا دائما في الخلايا الضامة و خلايا الطبقة الداخلية محتلا مكانا مميزا في السيتوبلازم فوق النواة. أما صبغ الأنوية فكان موجودا في غدد الرحم. أمـا أثتاء دورة الثـياع، فكـان المستقبل موجودا فقط في الخلايـا الضـامة بينما التسيج الطلائي الداخلى كان سالبا. في بداية الحمل عند اليوم 13 كان تعبير مستقبل الهيدروكربونات الطيارة متثابها مع فترة ما بعد الثباع • عضلات الرحم كانت دائما سالبة للمستقبل في هذه الدراسة. تلخيصا لما سبق، وجد أن مستقبل الهيدروكربونات الطيارة كان موجودا أثثاء فترة ما بعد الثباع و بداية الحمل في الطبقة الداخلية للرحم والجسم الأصفر في المبيض وكذا الخلايا الضامة في كل من

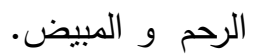

نتائج الدراسـة الحاليـة تشير إلي تغير في تعبير مستقبل الهيدروكربونات الطيارة في المبيض والرحم أثناء دورة الثياع وبداية الحمل تأثرا بالتغيرات الهرمونية في الأبقار . 